\title{
Analysis of Well Logs for Borehole ANL-OBS-A-001 at the Idaho National Engineering Laboratory, Idaho
}

By Frederick Paillet and Don Boyce

U.S. GEOLOGICAL SURVEY

Open-File Report 96-213 


\section{U.S. DEPARTMENT OF THE INTERIOR \\ BRUCE BABBITT, Secretary \\ U.S. GEOLOGICAL SURVEY \\ Gordon P. Eaton, Director}

The use of trade, product, industry, or firm names is for descriptive purposes only and does not imply endorsement by the U.S. Government.

For additional information write to:

Chief, Branch of Regional Research U.S. Geological Survey

Box 25046, MS 418

Denver Federal Center

Denver, CO 80225
Copies of this report can be purchased from:

U.S. Geological Survey

Earth Science Information Center

Open-File Reports Section

Box 25286, MS 517

Denver Federal Center

Denver, CO 80225 


\section{CONTENTS}

Abstract
Introduction
Drilling and logging operations
Geophysical logging equipment
Depth adjustment of borehole measurements
Analysis of borehole flow measurements
Correlation of geophysical logs with core
Comparison of conventional acoustic and shear suppression logs
Summary
References.

\section{FIGURES}

1. Map showing location of borehole ANL-OBS-A-001 at the Idaho National Engineering Laboratory ............... 3

2. Diagram showing borehole conditions during each of the four different phases of logging ............................. 5

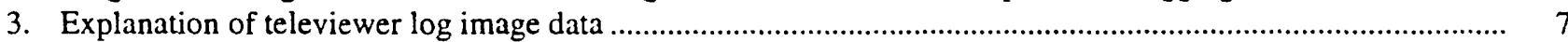

4. Gamma, neutron, short normal resistivity, fluid resistivity, temperature, caliper, and driller logs for borehole ANL-OBS-A-001

5. Gamma, neutron, short normal resistivity, fluid resistivity, temperature, and borehole televiewer logs, heat pulse flowmeter data, core description, and rock quality description (RQD) estimates based on core inspection for the depth interval from 635 to 840 feet

6. Gamma, neutron, acoustic velocity, short normal resistivity, fluid resistivity, temperature, caliper, and borehole televiewer logs, heat pulse flowmeter data, core description, and $\mathrm{RQD}$ estimates based on core inspection for the depth interval from 880 to 1100 feet

7. Gamma, neutron, acoustic velocity, short normal resistivity, fluid resistivity, temperature, and borehole televiewer logs, heat pulse flowmeter data, core description, and RQD estimates based on core inspection for the depth interval from 1735 to 1900 feet

8. Example of compressional (p) and shear (s) arrivals in near and far waveform signatures from waveform recordings obtained using the USGS conventional acoustic logging probe, arrival time picks, and computations used to determine compressional $\left(\mathrm{V}_{\mathrm{p}}\right)$ and shear $\left(\mathrm{V}_{\mathrm{s}}\right)$ velocities

9. Borehole televiewer log and acoustic velocity measurements given by the conventional acoustic $(34 \mathrm{kHz})$ and the shear suspension $(5 \mathrm{kHz})$ logging systems for the depth interval from 900 to 1140

10. Borehole televiewer log and acoustic velocity measurements given by the conventional acoustic and shear suspension logging systems for the depth interval from 1740 to 1760 feet.

11. Example of waveforms obtained near 1745 feet in depth using shear suspension and conventional acoustic logging systems and compressional (p) and shear (s) arrival time picks

\section{TABLES}

1. Chronology of events

2. Summary of geophysical equipment used to log borehole ANL-OBS-A-001

3. Comparison of specifications for shear suspension and conventional acoustic logging probes described in this report 


\begin{tabular}{rll}
\hline Multiply & By & To obtain \\
\hline cubic foot per second $\left(\mathrm{ft}^{3} / \mathrm{s}\right)$ & 0.02832 & cubic meter per second \\
foot $(\mathrm{ft})$ & 0.3048 & meter \\
inch (in.) & 25.4 & millimeter \\
mile (mi) & 1.609 & kilometer \\
square mile $\left(\mathrm{mi}^{2}\right)$ & 2.590 & square kilometer \\
\hline
\end{tabular}

Degree Celsius $\left({ }^{\circ} \mathrm{C}\right)$ may be converted to degree Fahrenheit $\left({ }^{\circ} \mathrm{F}\right)$ by using the following equation:

$$
{ }^{\circ} \mathrm{F}=9 / 5\left({ }^{\circ} \mathrm{C}\right)+32 \text {. }
$$

Degree Fahrenheit $\left({ }^{\circ} \mathrm{F}\right)$ may be converted to degree Celsius $\left({ }^{\circ} \mathrm{C}\right)$ by using the following equation:

$$
{ }^{\circ} \mathrm{C}=5 / 9\left({ }^{\circ} \mathrm{F}-32\right) \text {. }
$$

Sea level: In this report "sea level" refers to the National Geodetic Vertical Datum of 1929 (NGVD of 1929)--a geodetic datum derived from a general adjustment of the first-order level nets of both the United States and Canada, formerly called Sea Level Datum of 1929. 


\title{
Analysis of Well Logs for Borehole ANL-OBS-A-001 at the Idaho National Engineering Laboratory, Idaho
}

\author{
By Frederick Paillet and Don Boyce
}

\section{Abstract}

Geophysical well logs run under five different casing conditions during the drilling and removal of casing from borehole ANL-OBS-A-001 at the Idaho National Engineering Laboratory are presented with depth-adjustment for correlation with detailed core descriptions. Borehole televiewer image logs provide useful information regarding the details of fractures and basalt interflow openings in situ, and allow the proper positioning of fragmented core or recovered core sections where short intervals have been lost. Borehole flow logs indicate the specific features described on core and indicated on geophysical logs that are associated with inflow to or outflow from the borehole under ambient hydraulic head conditions. Acoustic logs and a short interval of acoustic waveform log data are used to evaluate the results from shear suspension logging as part of a seismic properties study designed to measure compressional and shear velocity at a scale of investigation larger than that associated with acoustic logs. The acoustic transit-time logs give measurements of acoustic transit time that agree with those from the suspension logging, except in the interval below 1735 feet in depth where the near receiver data obtained in the suspension logging were not reliable. However, comparison of waveforms obtained from the acoustic and suspension logging probes indicates that shear velocity estimated from the suspension $\log$ waveforms may underestimate formation shear velocity. This result is attributed to the known difference between shear wave group velocity and formation shear velocity for the suspension logging system.

\section{Introduction}

Core sample descriptions, geophysical well logs, and hydraulic measurements in boreholes are all accepted methods for characterizing aquifers in situ. Each method has specific advantages and drawbacks. For example, core description provides detailed and direct evidence of rock properties, but core recovery is often incomplete, and recovered samples are subject to damage and desiccation. Geophysical logs provide a complete and continuous sample of the formation adjacent to the well bore and usually provide information on the undamaged formation in situ, but logs provide measurements of properties such as gamma emission or electrical resistivity that are only indirectly related to properties of interest such as mineralogy and hydraulic conductivity. Hydraulic measurements are designed to provide information about aquifer properties of interest, but are influenced by the open borehole, or depend upon careful selection of isolation intervals. Even when sophisticated packer assemblies are used to isolate sampling intervals, previous movement of ground water along the open borehole can contaminate sampling zones.

In this report we describe the integration of results obtained from core description, geophysical well logs, and limited hydraulic and water-quality data obtained from fluid column resistivity and high-resolution flowmeter measurements in an open borehole (ANL-OBS-A-001) at the Idaho National Engineering Laboratory. Our intent is to produce a data set based on the depth correlation of all of these data containing information that would not be given by analysis of each data set alone. These results may be used by Argonne National Laboratory scientists in future monitoring, water sampling and hydraulic testing in borehole ANLOBS-A-001 and other adjacent boreholes. The report also identifies specific locations where apparent discrepancies between details of logs, flow data, and core descriptions indicate further analysis may be needed to resolve these inconsistencies. Finally, we compare acoustic waveform logs obtained with a conventional waveform logging system with those obtained by a sophisticated shear wave logging system. Both waveform logging approaches measure the compressional and shear velocity of the rocks adjacent to the borehole, but each uses different acoustic source mechanisms, 
and each involves different scales of investigation. We document the depth-adjusted comparison of these two data sets because the information obtained at different scales may provide useful insights when compared to core descriptions for the same depth interval.

\section{Drilling and Logging Operations}

The location of borehole ANL-OBS-A-001 is shown in figure 1. A summary of drilling and logging events is given in table 1. Borehole ANL-OBS-A-001 was drilled in stages, and collapse of materials from rubble zones between basalt flows was a constant hazard during drilling. The first stage consisted of drilling an approximately 4 -inch-diameter corehole to water level at about 640 feet in depth, enlargement of the corehole to about 8 inches in diameter, and installation of a plastic casing with 4-inch inside diameter. Preliminary caliper and gamma logs were obtained in the corehole before enlargement and installation of casing under the open hole conditions indicated as logging run 1 in figure 2 and table 1.

Coring was continued in the cased borehole to a depth of about 1735 feet. At that time the hollow drill stem was left in place to serve as a casing, and drilling continued to a total depth of about 1910 feet using a slightly smaller diameter drill string inside the 3 -inchdiameter casing. At the completion of drilling, logging run 2 was performed (gamma and neutron logs) inside the hollow drill stem under the casing configuration indicated in figure 2 . The drill string was then withdrawn, and open hole logs (gamma, acoustic, shear suspension, resistivity, temperature, fluid conductivity, caliper, televiewer, and flowmeter logs) were run in the open hole below $1735 \mathrm{ft}$ in depth (logging run 3; fig. 2).

After the lower open borehole was logged, the driller attempted to provide open hole logging in the cased interval by withdrawing casing in stages. However, casing could not be withdrawn from the interval immediately above 1735 feet in depth. The casing was cut at several locations between 1735 and 1200 feet in depth, and logging performed in two stages as casing was removed. The first stage allowed open hole logging from the casing cut at 1190 feet to the bottom of casing at 860 feet (caliper, gamma, acoustic, shear suspension, resistivity, fluid resistivity, temperature, televiewer, and flowmeter logs) in logging run 4 (fig. 2). The second stage of casing withdrawal allowed logging from 860 feet to water level near the bottom of the plas- tic surface casing (caliper, gamma, shear suspension, resistivity, fluid resistivity, temperature, televiewer, and flowmeter logs; logging run 5, fig. 2).

\section{Geophysical Logging Equipment}

The geophysical logging equipment run by the U.S. Geological Survey in borehole ANL-OBS-A-001 provided a full suite of conventional geophysical logs. These logs included gamma, long and short normal resistivity, single point resistance, acoustic transittime, temperature, fluid resistivity, caliper, heat-pulse flowmeter, and borehole televiewer logs. All of these logs except the flowmeter and televiewer logs were provided as digital files of data in the form of physical measurement and depth at which the measurement was made, given at 0.1 foot depth intervals (Keys, 1990). The televiewer log data were provided as photographic images of the pattern of acoustic reflectivity of the borehole wall (Paillet, 1993; Paillet and others, 1987). The flowmeter data were provided as lists of vertical flow along the borehole at discrete depth locations (Hess, 1986; Paillet and others, 1987). A summary of log measurements, tool specifications, and standard applications is given in table 2. A summary of televiewer image data presentations used in this study is given in figure 3. Additional information on the interpretation of geophysical logs in ground water studies can be obtained from a number of textbooks and manuals, including Keys (1990), Hearst and Nelson (1985) and Paillet (1993).

Although the U.S. Geological Survey acoustic logs were not expected to provide more information about formation properties than would be given by gamma, neutron, and resistivity logs, the acoustic logs were run for comparison with shear suspension logs run at the same time as part of a seismic properties study. The shear suspension logging system is designed to provide information about both compressional and shear velocity of the formation adjacent to the borehole at a scale somewhat larger than that associated with conventional acoustic logs (Kitsunezaki, 1980; White, 1983). A comparison of the characteristics of the conventional acoustic and shear suspension logging systems used in this study is given in table 3. 




Figure 1. Location of borehole ANL-OBS-A-001 at the Idaho National Engineering Laboratory. 
Table 1. Chronology of events

\begin{tabular}{|c|c|}
\hline Date & Event \\
\hline $6-30-94$ & Drilling started \\
\hline 7-13-94 & Completion of first increment of corehole. \\
\hline $7-14-94$ & Logging of upper corehole (caliper, gamma; logging run 1). \\
\hline 8-03-94 & Upper corehole reamed and casing cemented. \\
\hline 8-18-94 & Coring resumes below 650 feet in depth. \\
\hline $1-11-95$ & Coring completed at total depth of 1910 feet below land surface. \\
\hline $1-11-95$ & Neutron and gamma logs run inside drill stem over entire borehole (logging run 2). \\
\hline $1-23-95$ & $\begin{array}{l}\text { Shear wave logging performed in open borehole below } 1735 \text { feet in depth (logging } \\
\text { run 3). }\end{array}$ \\
\hline $1-24-95$ & $\begin{array}{l}\text { Open-hole geophysical logs were run in open borehole below } 1735 \text { feet in depth (log- } \\
\text { ging run 3). }\end{array}$ \\
\hline $1-26-95$ & $\begin{array}{l}\text { Open-hole geophysical logs run over interval from } 1190 \text { to } 860 \text { feet in depth after par- } \\
\text { tial removal of casing (logging run 4). }\end{array}$ \\
\hline $1-26-95$ & $\begin{array}{l}\text { Open-hole geophysical logs run over interval from } 860 \text { to } 650 \text { feet in depth after addi- } \\
\text { tional casing removed (logging run } 5 \text { ). }\end{array}$ \\
\hline 2-09-95 & Borehole ANL-OBS-A-001 completed as observation borehole. \\
\hline
\end{tabular}



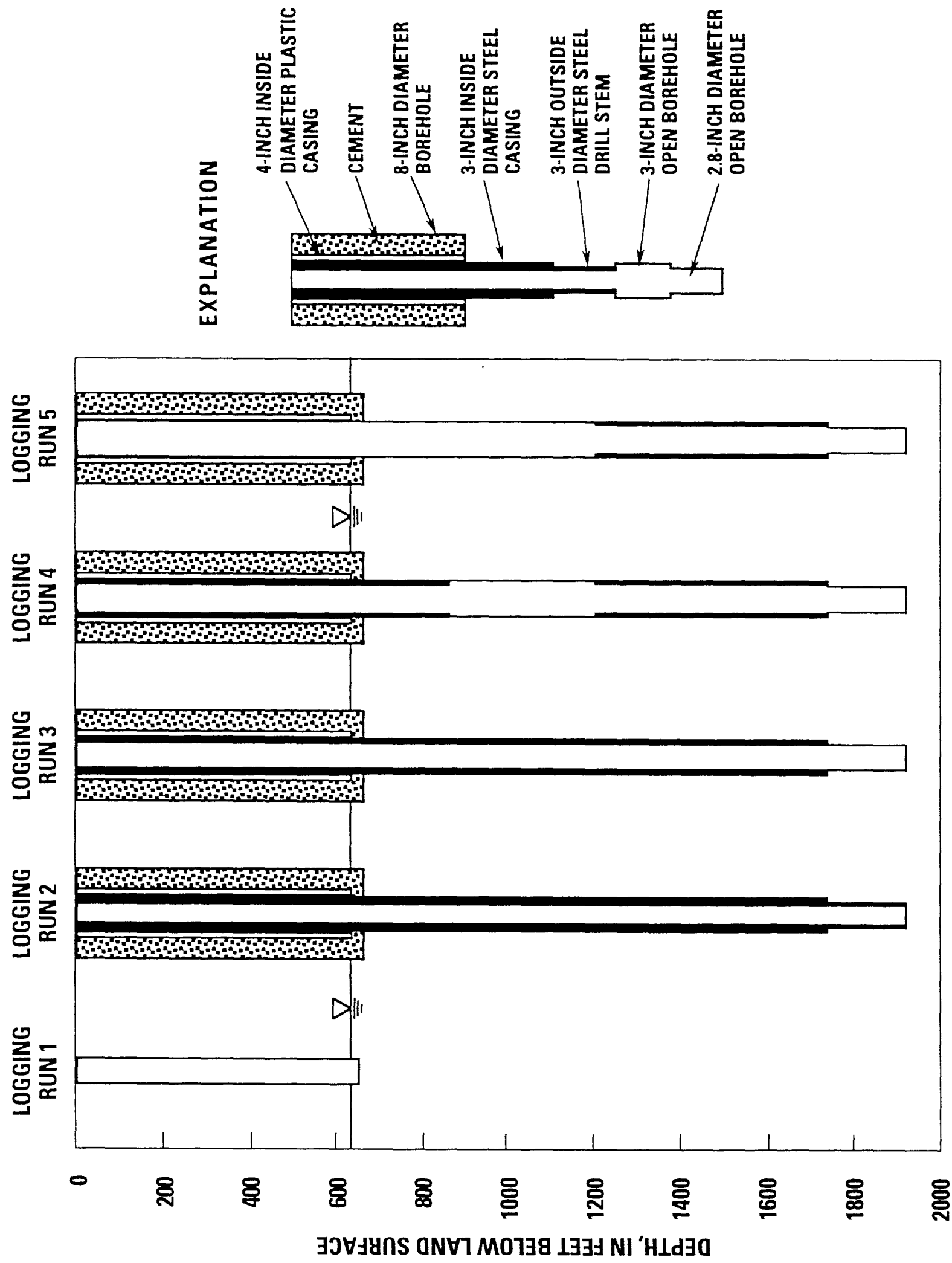

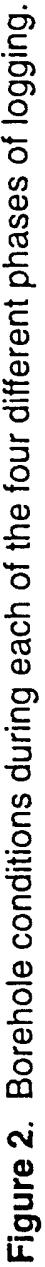


Table 2. Summary of geophysical equipment used to log borehole ANL-OBS-A-001.

[ft, feet; $\mathrm{kHz}$, kilohertz; $\mathrm{MHz}$, megahertz]

\begin{tabular}{|c|c|c|c|}
\hline Log type & Specifications & Property measured & $\begin{array}{l}\text { Conventional } \\
\text { application }\end{array}$ \\
\hline Caliper & Three 3-inch arms & Borehole diameter & Fracture identification \\
\hline Gamma & Nal Crystal & Gamma activity & $\begin{array}{l}\text { Stratigraphy and lithol- } \\
\text { ogy }\end{array}$ \\
\hline Neutron & He (thermal) detector & $\begin{array}{l}\text { Neutron flux attenua- } \\
\text { tion }\end{array}$ & Porosity \\
\hline Normal resistivity & 16 and 64-inch spacing & Formation resistivity & Lithology and porosity \\
\hline Single-point resistivity & Differential electrodes & Bulk resistance & Fracture identification \\
\hline Acoustic transit-time & $\begin{array}{l}35 \mathrm{kHz} \text { source } \\
3 \mathrm{ft} \text { spacing }\end{array}$ & Acoustic velocity & Lithology and porosity \\
\hline Temperature & $\begin{array}{l}\text { Fluid column measure- } \\
\text { ment }\end{array}$ & $\begin{array}{l}\text { Borehole fluid tempera- } \\
\text { ture }\end{array}$ & $\begin{array}{l}\text { Borehole flow and } \\
\text { water quality }\end{array}$ \\
\hline Fluid resistivity & $\begin{array}{l}\text { Fluid column measure- } \\
\text { ment }\end{array}$ & Borehole fluid resistivity & $\begin{array}{l}\text { Borehole flow and } \\
\text { water quality }\end{array}$ \\
\hline Televiewer & $\begin{array}{l}1.25 \mathrm{MHz} \\
3 \text { rps scan }\end{array}$ & Borehole wall image & Fracture identification \\
\hline Flowmeter & Heat-pulse flowmeter & Net borehole flow & $\begin{array}{l}\text { Entry and exit points for } \\
\text { flow }\end{array}$ \\
\hline Shear suspension ${ }^{1}$ & $5 \mathrm{kHz}$ dipole source & $\begin{array}{l}\text { Formation shear veloc- } \\
\text { ity }\end{array}$ & Seismic rock properties \\
\hline
\end{tabular}

1. This log run by a private contractor; all other logs were run by the U.S. Geological Survey. 


\section{EXPLANATION OF TELEVIEWER LOGS}

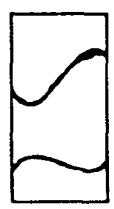

Isolated planes intersecting borehole; probably open fractures.

Fracture zone composed of several parallel and intersecting fractures.

Faint discontinuous planes intersecting borehole; probably foliation in greenschist.

Large opening intersecting borehole; shape of top of opening may indicate orientation.

Intensely fractured and altered rock; orientation of individual fractures difficult to determine.

Bottom of casing above open borehole.

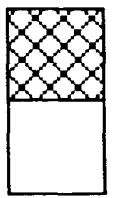

Top of fluid column in open borehole.

Lowermost interval of borehole inaccessible to televiewer.

Figure 3. Explanation of televiewer log image data. 
Table 3. Comparison of specifications for shear suspension and conventional acoustic logging probes described in this report.

[kHz, kilohertz; ft, feet]

\begin{tabular}{|c|c|c|c|c|}
\hline \multirow{2}{*}{ Tool type } & \multirow{2}{*}{ Source type } & \multirow{2}{*}{$\begin{array}{c}\text { Source } \\
\text { frequency }\end{array}$} & \multirow{2}{*}{$\frac{\text { Receiver }}{\text { Near }}$} & \multirow{2}{*}{$\frac{\text { Separations }}{\text { Far }}$} \\
\hline & & & & \\
\hline Shear suspension & Dipole $^{1}$ & $5 \mathrm{kHz}$ & $7.5 \mathrm{ft}$ & $10.3 \mathrm{ft}$ \\
\hline $\begin{array}{l}\text { Conventional } \\
\text { acoustic }\end{array}$ & Monopole ${ }^{2}$ & $34 \mathrm{kHz}$ & $2.0 \mathrm{ft}$ & $5.0 \mathrm{ft}$ \\
\hline
\end{tabular}

1. Dipole source is characterized by a nonaxisymmetric forcing in the borehole with very little net volumetric dilatation; such sources excite more shear vibration and less compressional vibration adjacent to boreholes than sources where there is substantial dilatational motion (Kitsunezaki. 1980; Chen, 1988).

2. Monopole source is the conventional borehole acoustic logging source; this source produces an axisymmetric forcing of motion which consists of an alternate expansion and contraction of a magnetostrictive or piezoelectric transducer. Such source excitation is mostly dilatational and therefore excites strong compressional waves in the formation around the borehole, although shear motion may also be induced, with shear amplitude dependent on the seismic properties of the formation and the annulus width between logging tool and borehole wall (Paillet and Cheng, 1986; White, 1983). 


\section{DEPTH ADJUSTMENT OF BOREHOLE MEASUREMENTS}

Most borehole depth measurement systems provide depth measurements to within an accuracy of better than 1 percent. Although this seems to be a very precise measurement, different depth measurement systems have slightly different degrees of error, and depth reference points can sometimes differ by a few feet. When boreholes are more than several hundred feet deep, very small depth errors can amount to more than 1 foot even when there are no surface reference point differences. Because most logging tools have a sample volume about 1 foot in diameter, depth scale differences of 1 foot or more can cause two different measurements at the same nominal depth to refer to different sample volumes. These errors are overcome in geophysical log analysis by correlating different logs and geological descriptions so that the pattern of geophysical log variation is correlated with the series of geologic properties described for core. In the data correlation described in this report, we use the pattern of geophysical log variation with depth to correlate logs and core description by matching marker beds and the contacts between basalt flows. Marker beds in the form of clay-mineral rich sediments and the prominent contacts between certain basalt flows are readily recognized on both the core and the logs. We have used the depth scale given by the one logging tool used to collect the largest number of logs (a multi-function logging probe giving gamma, resistivity, single-point resistance, temperature, and fluid resistivity logs) as the nominal depth scale for the depth adjustment. All other data, including caliper, neutron, televiewer logs, core descriptions, and heat-pulse flowmeter measurements, have been adjusted to give the best correlation with these logs. After completing the adjustment, the correlated data set allow us to unambiguously associate a given geophysical log response or a given amount of inflow to the borehole with specific features identified on the televiewer image log, or indicated on the core description. Because the maximum depth shift required for the correlation was less than 15 feet over a total depth of about 1900 feet, the depth scale given on the log composites is considered to be accurate to within 1 percent.

Selected geophysical logs (gamma, neutron, resistivity, fluid resistivity, temperature and caliper logs) are compared to a generalized drillers log for borehole ANL-OBS-A-001 in figure 4. The drillers log notes those intervals where unstable borehole conditions affected drilling. The gamma and neutron logs were obtained on logging run 2 . The temperature and fluid resistivity logs were obtained on run 3 with only the interval below 1735 open to the formation. The other logs given in figure 4 were obtained as discontinuous intervals on logging runs 3,4 , and 5. More detailed correlation between geophysical logs (gamma, neutron, acoustic, resistivity, fluid resistivity, temperature, caliper, and televiewer logs), core descriptions, and flowmeter data are given in figures 5,6, and 7 for the intervals logged on logging runs 3,4 , and 5 . These composite figures are constructed with data presented so that logs most often interpreted in terms of formation lithology (gamma, neutron, and resistivity) are on the left of the figure; the logs most often interpreted in terms of fractures (caliper and televiewer) are compared to the core description in the center of the figure; and the logs most often interpreted in terms of borehole flow (fluid resistivity and temperature) are compared to the flowmeter data on the right of the figure.

\section{ANALYSIS OF BOREHOLE FLOW MEASUREMENTS}

Open boreholes in basalt flows such as those penetrated by borehole ANL-OBS-A-001 provide hydraulic connections between previously isolated fractures and rubble zones between solid flows. Ambient hydraulic head differences between these permeable openings can induce flow along the borehole. Measurement of these flows indicates those features associated with inflow to and outflow from the borehole. The ambient borehole flow also indicates the depths where water sampled from the borehole fluid column entered the borehole. High-resolution borehole flow measurements were made in borehole ANLOBS-A-001 with the U.S. Geological Survey heat pulse flowmeter. This device can detect flow as small as 0.01 gallon per minute (Hess, 1986; Paillet, 1993).

Measurable flows were detected in borehole ANL-OBS-A-001 during logging runs 3, 4, and 5 (figs. 5,6 , and 7) under the casing configurations indicated for these logging runs in figure 2 . The flow regime in the lowermost open hole interval logged consisted of inflow near 1810 feet in depth, and outflows near 1760 and 1835 feet in depth (fig. 7). Note that downflow from permeable intervals above 1735 feet was prevented by the solid casing present above that depth at the time of logging. 


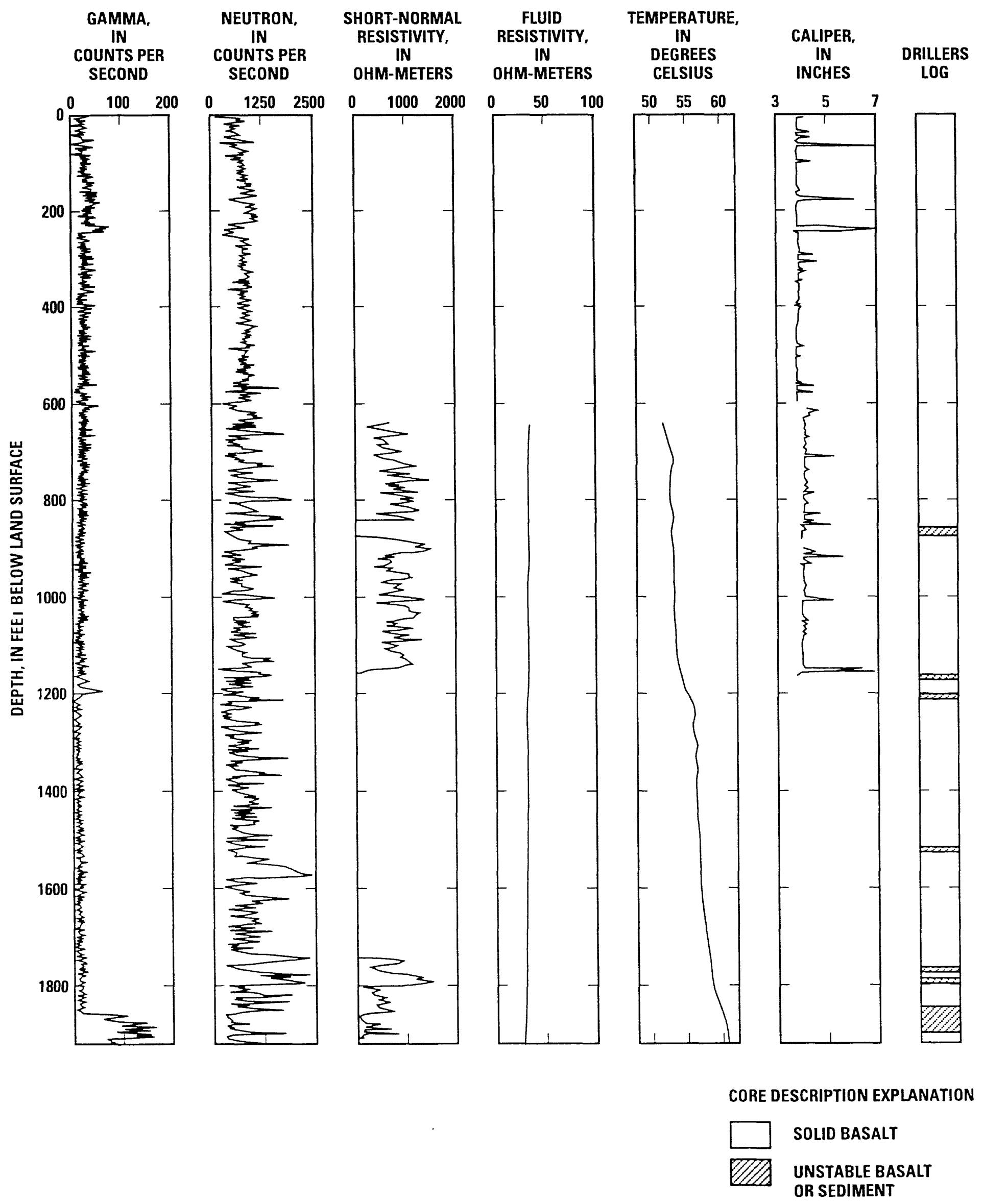

Figure 4. Gamma, neutron, short normal resistivity, fluid resistivity, temperature, caliper, and driller logs for borehole ANL-OBS-A-001. 



㟝岂

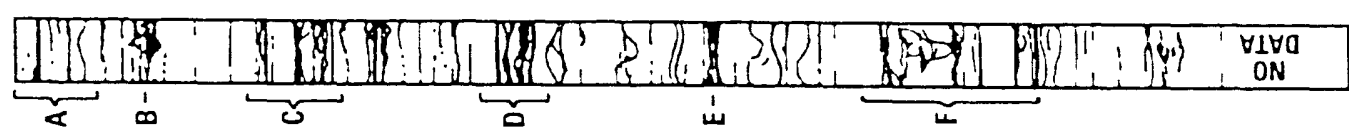

突恣

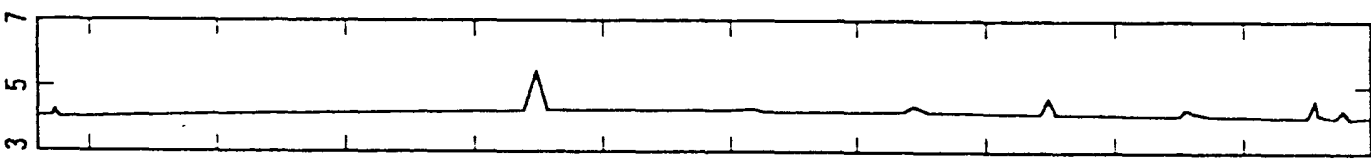

市之
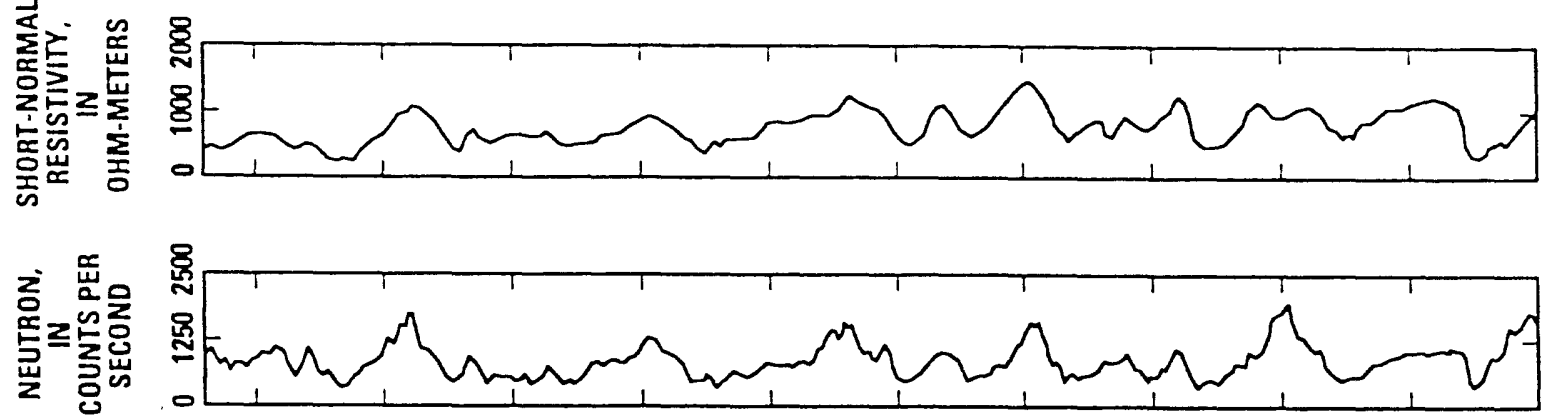

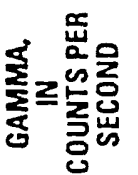

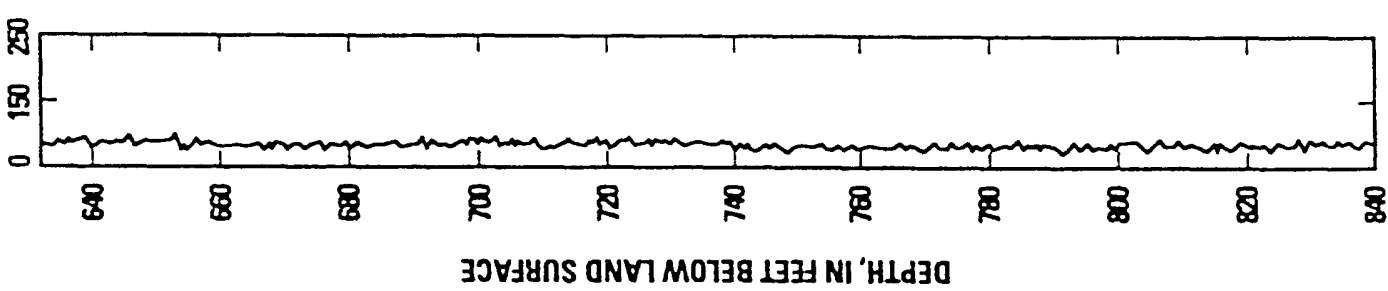



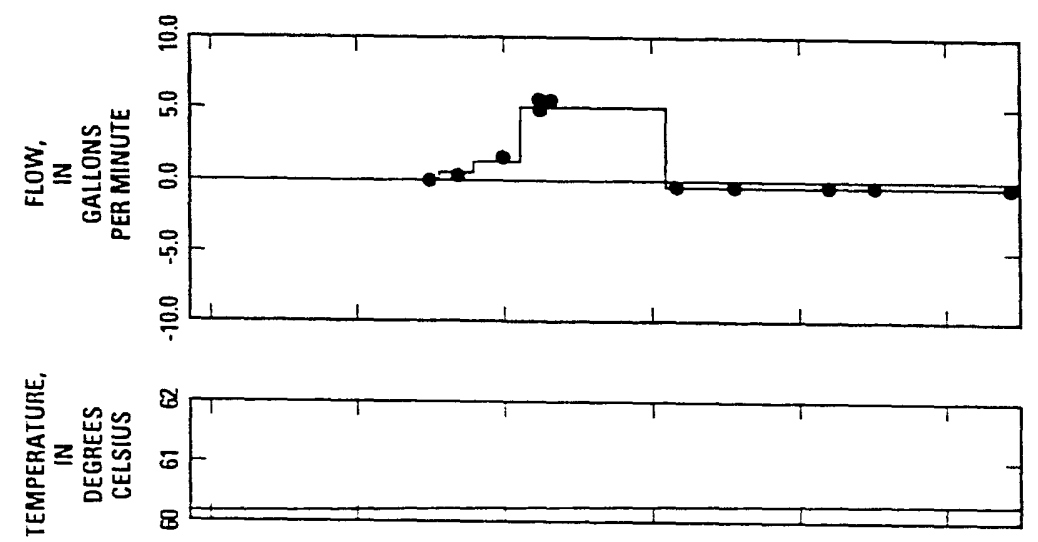

\%ั


ऐ)

.

옹요

용

잉

응

을

क.

응 䎹

$\Phi$

$\stackrel{2}{ \pm}$

뜬응

응드

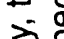

के



需

ฏ 잉

끅 등
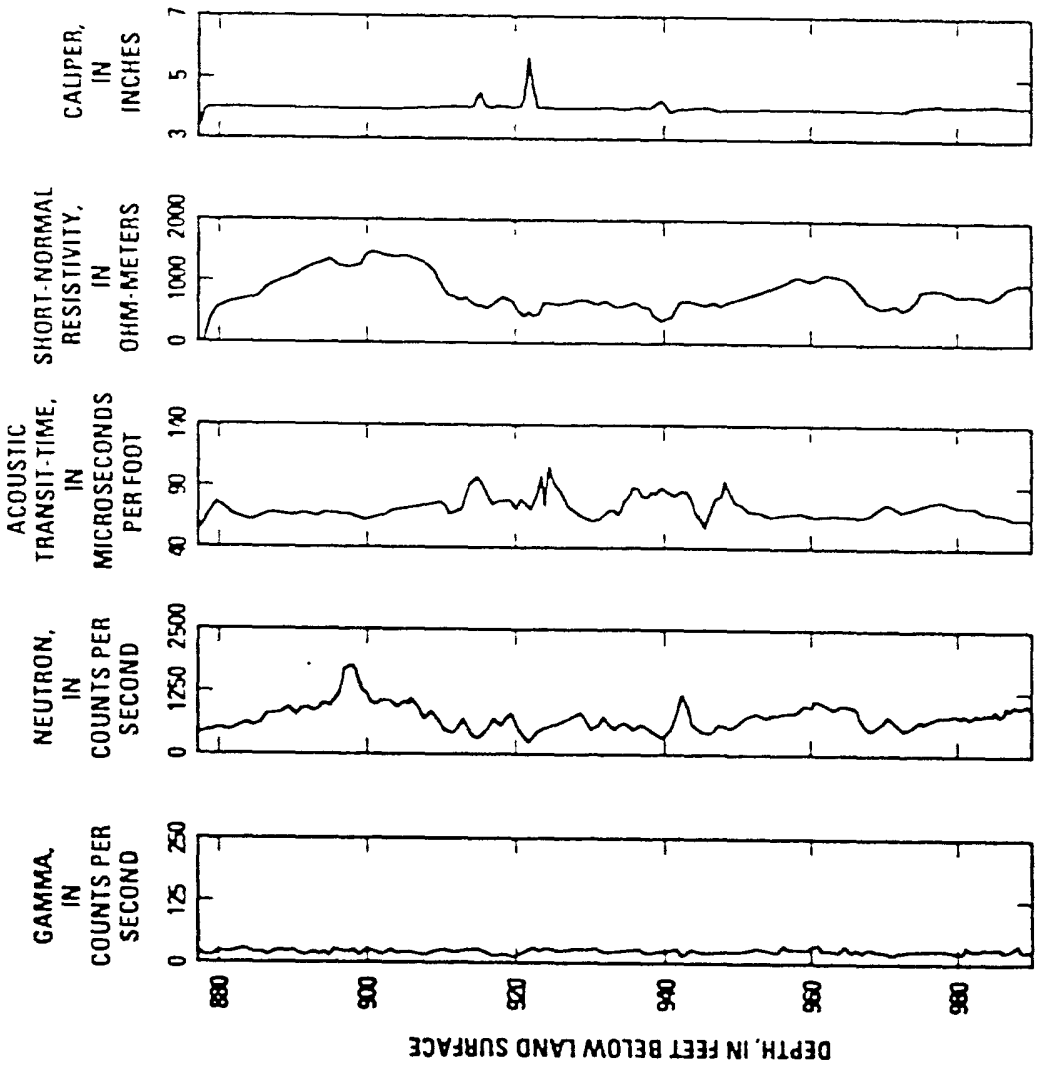




The flow regime during logging run 4 consisted mostly of downflow from a permeable opening near 940 feet in depth (about 80 feet below what was then the bottom of casing) (fig. 6). This downflow was augmented by additional inflow at other openings (mostly basalt flow contacts) in the interval from 1000 to 1090 feet in depth. The flow continued into the borehole below a constriction at about 1150 feet in depth which prevented access by all logging tools except for the slim caliper tool. The exit point for this downflow could have been the large opening just below 1150 feet in depth indicated by the caliper log, or the open hole below the interval of casing from 1190 to 1735 feet in depth. The flowmeter log also indicated a short interval of upflow (910-940 ft). Again, potential inflow from intervals above 860 feet in depth was prevented by the presence of casing during logging run 4 .

The flow regime during logging run 5 consisted of inflow from a permeable opening near 710 feet in depth, additional inflow from another opening near 740 feet in depth, and outflow into the open borehole below 840 feet in depth. The downflow could not be traced below 840 feet in depth because borehole conditions limited tool access below that depth. There was also a short interval of upflow from 670 to 710 feet in depth. All of these flow data are consistent with a large-scale regime characterized by decreasing hydraulic head with depth, and a heterogeneous distribution of fracture and interflow permeability.

\section{CORRELATION OF GEOPHYSICAL LOGS WITH CORE}

The correlation of geophysical logs with core is given in figures 5, 6, and 7. The figures generally show that most of the basalt flow tops and bottoms indicated on the core description are shown on the televiewer image log. The flowmeter measurements allow identification of inflow and outflow to the borehole under ambient hydraulic head conditions, and the association of those inflow and outflow points with specific features indicated on the logs. A detailed discussion of features which correlate across the logs and core description is given as follows, with the description keyed to upper case letters given on the figures sequentially from the top of figure 5 to the bottom of figure 7 . These comments are by no means all of the correlations between logs and core that might be of interest, but they serve as examples of the way in which the two classes of data can be integrated, and point out a few places where minor discrepancies between log and core need to be reconciled.

A. Although the top of this basalt flow is indicated on the core description, a prominent horizontal feature that looks like a flow contact is shown by the televiewer log in the center of the flow.

B. This flow contact appears more complex than a simple planar contact, and seems to correspond with a rubble zone that may contain altered clays. That conclusion is supported by a weak gamma high and lows on the neutron and resistivity logs, each of which may indicate the presence of clay minerals.

C. Another major horizontal break shown on the televiewer log, but not on the core, apparently contains altered clays, as indicated by the neutron and resistivity logs. This opening, or the flow contact just below, is an outflow point for water moving up the borehole, as indicated by both the discrete flowmeter data and the change in the fluid resistivity profile.

$D$. The top and bottom of this basalt flow appear to be slightly off on the core description, perhaps due to a short core loss because the televiewer depth scale is continuous in this interval. The breaks within this flow are clearly the source of the inflow to the borehole under ambient conditions.

E. This prominent feature does not correlate very well with the basalt flow bottom, but is another source of inflow to the borehole.

F. Some of the horizontal features shown on the televiewer log correlate very well with the tops and bottoms of basalt flows on the core, but one prominent horizontal feature does not.

G. The basalt flow tops and bottoms correlate well on core and televiewer, while the low values on resistivity and neutron logs and the high value on acoustic log indicate altered clays or borehole enlargement and cycle skipping for the thin clay bed. The lowermost opening in this interval is a major outflow point according to both flowmeter and fluid resistivity logs.

$\mathrm{H}$. The basalt flow contacts on the core appear as three parallel contacts on the televiewer and correspond to a major inflow point.

I. Although this feature is shown as a basalt flow contact on the core description, it is clearly a complex feature on the televiewer $\log$, which corresponds to resistivity and neutron log lows indicative of altered clays or to borehole enlargement on the caliper log. Although the caliper indicates a big opening in the borehole wall, only a small amount of flow actually enters the borehole here. 
J. The basalt flow contact at the bottom of this interval is very apparent on the televiewer $\log$, but there seem to be other planar openings within the flow. The other logs indicate some altered clays may be associated with all of these openings, indicating that the interior of this flow is somewhat different from the interior of the thick flow just above.

$\mathrm{K}$. The televiewer only weakly expresses the basalt flow contact (if at all), while there is a prominent, steeply dipping fracture just below. One of these two features is a major conduit for inflow to the borehole. If the flow comes from the fracture, the orientation of the fracture with respect to the ambient stress field may indicate something about the relationship between state of stress and regional permeability. The other logs indicate some clay alteration may be present.

L. The basalt flow contact on the core corresponds with a major, steeply dipping fracture on the televiewer log with about the same strike and somewhat more dip than the fracture discussed above.

M. The log signature here is unusual. The acoustic $\log$ indicates mostly solid rock, while the resistivity and neutron logs indicate major clay content or porosity. This is an indicator of cavernous permeability. The acoustic energy could propagate up the intact side of the borehole while the neutron and resistivity logs may indicate a large opening intersecting only one side of the hole. A possible explanation is that the outside of the hole "grazes" some kind of opening, which would not be detected in the core. A large "opening" is indicated on the north side of the televiewer image. This opening may be the outlet for the flow which exits in this depth interval.

$\mathrm{N}$. This clay bed on the core closely correlates with a horizontal bed on the televiewer log, and with clay indicators gamma, neutron, and resistivity logs. However, it is unusual that the acoustic log does not show any anomaly corresponding to the anomalies on the other logs.

O. This basalt flow is broken into rubble according to the televiewer log, which corresponds to a strong spike of cycle skipping on the acoustic log. The lack of a gamma anomaly and the weak resistivity low indicates that the stronger neutron low corresponds to effective porosity and not the noneffective porosity of clay. This zone is a major inflow zone for the ambient flow regime at the time of logging.

P. A major outflow in ambient flow clearly corresponds with the flow contact here, as indicated by both flowmeter and temperature logs.
Q. All logs clearly and unambiguously show the abrupt change in lithology indicated at this depth on core.

$R$. The thin clay bed described here on core closely correlates with the indication of that bed on the televiewer log. This clay bed does not show a gamma high and is just below a gamma low, the exact opposite gamma log response expected from clay beds.

\section{COMPARISON OF CONVENTIONAL ACOUSTIC AND SHEAR SUPPRESSION LOGS}

Conventional acoustic logs provide measurements of acoustic transit time, the inverse of compressional velocity in the formation adjacent to the borehole. The acoustic logging probe detects the arrival of the acoustic signal at two receiver locations uphole from the acoustic source. The difference in arrival time is divided by the receiver separation to give the transit-time expressed in microseconds per foot. This measurement is designed to subtract out the "fluid delay" associated with the propagation of the acoustic signal from the source to the borehole wall, and from the borehole wall to the receiver (Paillet and Cheng, 1991).

One of the most common sources of error in acoustic logging is caused by errors known as "cycle skips" related to the inability of the electronics in the logging probe to detect the first acoustic arrival. If errors occur as isolated data points in the log, simple curve smoothing and other techniques can be used to correct the log. However, if such errors occur over substantial depth intervals, the acoustic log may give an incorrect measurement of acoustic transit-time in the formation. The proper functioning and especially the correct detection of arrival times by the acoustic logging system can be checked by recording the entire waveform signal at each receiver during the logging. The waveforms can be plotted and the arrivals indicated by the plots used to compute transit times that can be checked against those given by the acoustic logs.

Acoustic waveforms were recorded on a repeat acoustic logging run over the interval from 1735 to 1800 feet in depth in borehole ANL-OBS-A-001. A sample set of waveforms is illustrated in figure 8. The waveforms clearly show the arrivals of both compressional and shear waves at near and far receivers. The compressional transit time computed from the arrivals in the data give a value of 61.3 microseconds per foot. 
This value agrees exactly with that given by the log, confirming the proper functioning of the acoustic logging probe for this one data point.

Our analysis of the waveform data indicate that the acoustic log gives effective measurements of compressional transit time in all intervals where unfractured rock can conduct compressional waves along the borehole from source to receiver. In those intervals where fractures or basalt flow contacts attenuate the acoustic signal, the acoustic logging probe may fail to detect the first compressional arrival at one or both receivers, causing the logging tool to give an incorrect measurement of acoustic transit time. This result indicates that the acoustic transit-time values given by the acoustic logging probe can only be considered reliable in the unfractured interior of individual basalt flow units.

One of the important applications of acoustic log data in analysis of the borehole ANL-OBS-A-001 data is as a check on compressional and shear velocity measurements obtained with another acoustic logging system designed to provide data for use in surface seismic interpretation. This logging system is designed to produce seismic waves (compressional and shear) at frequencies and wavelengths closer to those of surface seismic prospecting than those used in conventional acoustic logging. This low-frequency tool is referred to as a shear suspension logging system (Kitsunezaki, 1980). The characteristics of the shear suspension and conventional acoustic logging systems are compared in table 3. The compressional transit time given by the conventional acoustic $\log$ and the shear suspension log are compared for the 900-1140 foot interval in figure 9 and for the 1745-1775 foot interval in figure 10 .

The transit time values given by the two logging systems are nearly identical in figure 9 . The data have been depth-adjusted to match borehole conditions indicated by the televiewer image log. The higher frequency and smaller compressional wavelength of the conventional $\log$ data result in the conventional transittime values being more sensitive to local borehole conditions. At least some of this apparent sensitivity results from cycle skipping in the vicinity of flow contacts, fractures, and borehole wall enlargements attributed to other factors. Otherwise, the agreement between the two independent measurements of acoustic transit time indicates that the values of compressional velocity given by the logs are correct, while the larger scale of investigation of the suspension log indicates that the suspension log data are the more likely to correspond with seismic velocities measured by conventional seismic sounding than the conventional acoustic log data.

No waveform data were obtained in the 900 1140 foot depth interval because the set of waveform data obtained in the 1740-1780 foot interval was considered adequate to check the correspondence between shear values given by the conventional log waveform analysis and the shear suspension log analysis. However, near receiver failure in the suspension logging of the 1740-1780 foot interval made the analysis of the suspension shear log data more difficult. Comparison of the compressional transit-time data given by the suspension log analysis (based on only the far receiver waveform data) to the data given by the conventional acoustic log analysis indicates a significant difference in measured compressional transit times (fig. 10).

Inspection of the compressional wave data for the far receiver shows that the far receiver arrivals are not very good in the shear suspension log data. The poor quality of the compressional data may explain the differences in the data in figure 10. Inspection of the conventional $\log$ waveforms (fig. 8) indicates that definite compressional arrivals can be identified in the data, and that the transit times picked from the conventional acoustic logging system waveforms agree exactly with those given by the conventional acoustic log. This observation indicates that the acoustic arrival picking electronics in the conventional acoustic logging system are correctly determining compressional velocity in the basalt. The waveforms obtained with the conventional $\log$ also contain shear arrivals which can be compared to the shear arrivals in the waveforms from suspension $\log$ waveforms (fig. 11). In this analysis, the time scale of the two waveforms is normalized using the source/ receiver separation and the average compressional velocity:

$$
\mathrm{T}=\mathrm{t} * \mathrm{~V}_{\mathrm{p}} / \mathrm{D}
$$

where $\mathrm{T}$ is the normalized time (nondimensional), $t$ is the time scale on the waveforms in seconds, $V_{p}$ is the interval-averaged compressional velocity $(16,313 \mathrm{ft} / \mathrm{s})$ in figure 9 , and $D$ is the source/receiver separation (10.3 feet for the shear suspension log data and 2.0 feet for the conventional acoustic log data). Because there may have been some depth offset between the two different logs run at different times and using different winch systems, the waveforms were selected for an interval just below the bottom of casing (near 1745 feet in depth) where both logs showed little variation in the 


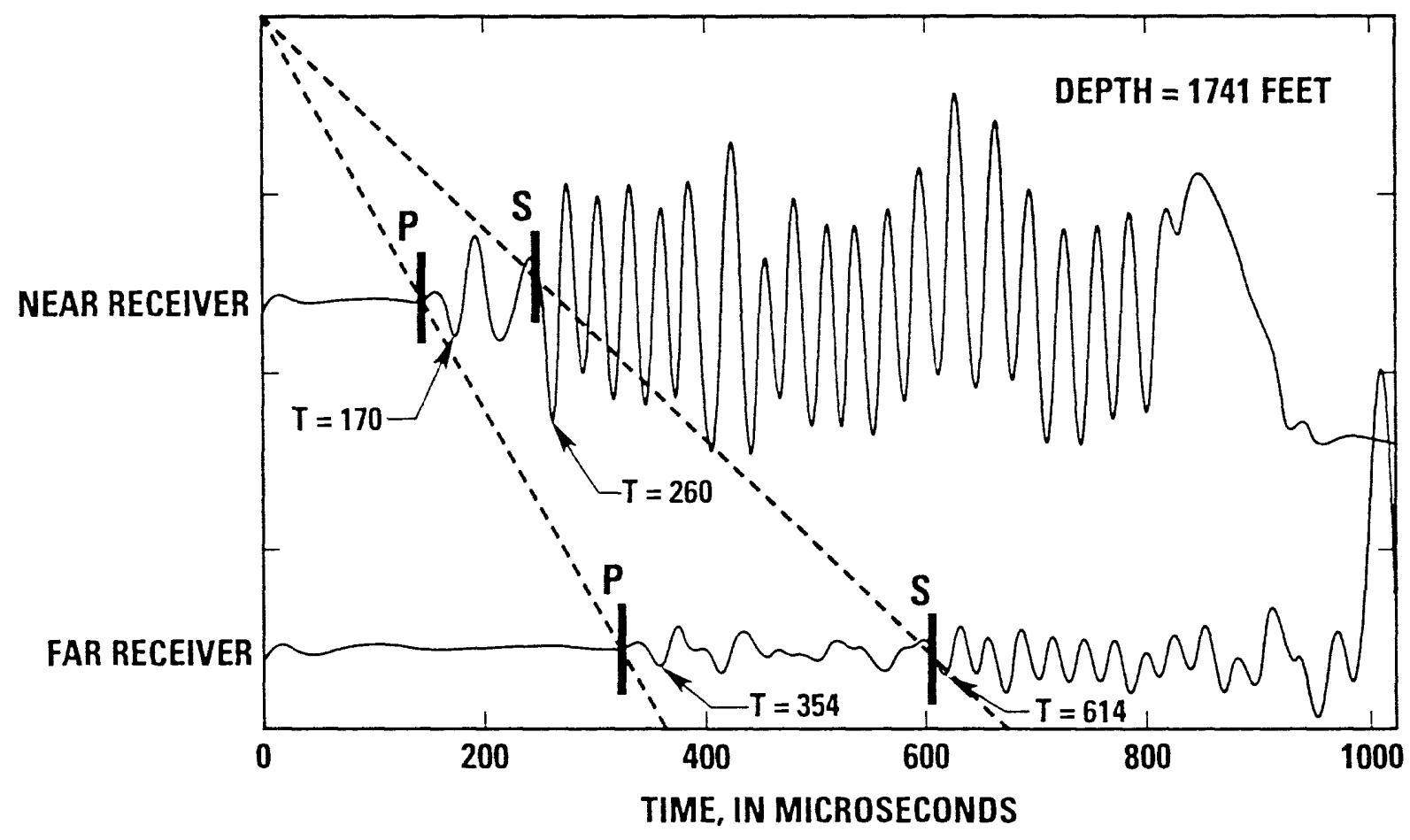

$$
\begin{gathered}
\Delta \mathrm{T}_{\mathrm{P}}=\frac{354-170}{3 \mathrm{FT}} \mu \mathrm{S}=61.3 \mu \mathrm{S} / \mathrm{FT} \\
\mathrm{V}_{\mathrm{P}}=16,313 \mathrm{FT} / \mathrm{S} \\
\Delta \mathrm{T}_{\mathrm{S}}=\frac{614-260}{3 \mathrm{FT}} \mu \mathrm{S}=118 \mu \mathrm{S} / \mathrm{FT} \\
\mathrm{V}_{\mathrm{S}}=8,470 \mathrm{FT} / \mathrm{S}
\end{gathered}
$$

Figure 8. Example of compressional $(p)$ and shear (s) arrivals in near and far waveform signatures from waveform recordings obtained using the USGS conventional acoustic logging probe, arrival time picks, and computations used to determine compressional $\left(V_{p}\right)$ and shear $\left(V_{s}\right)$ velocities. 


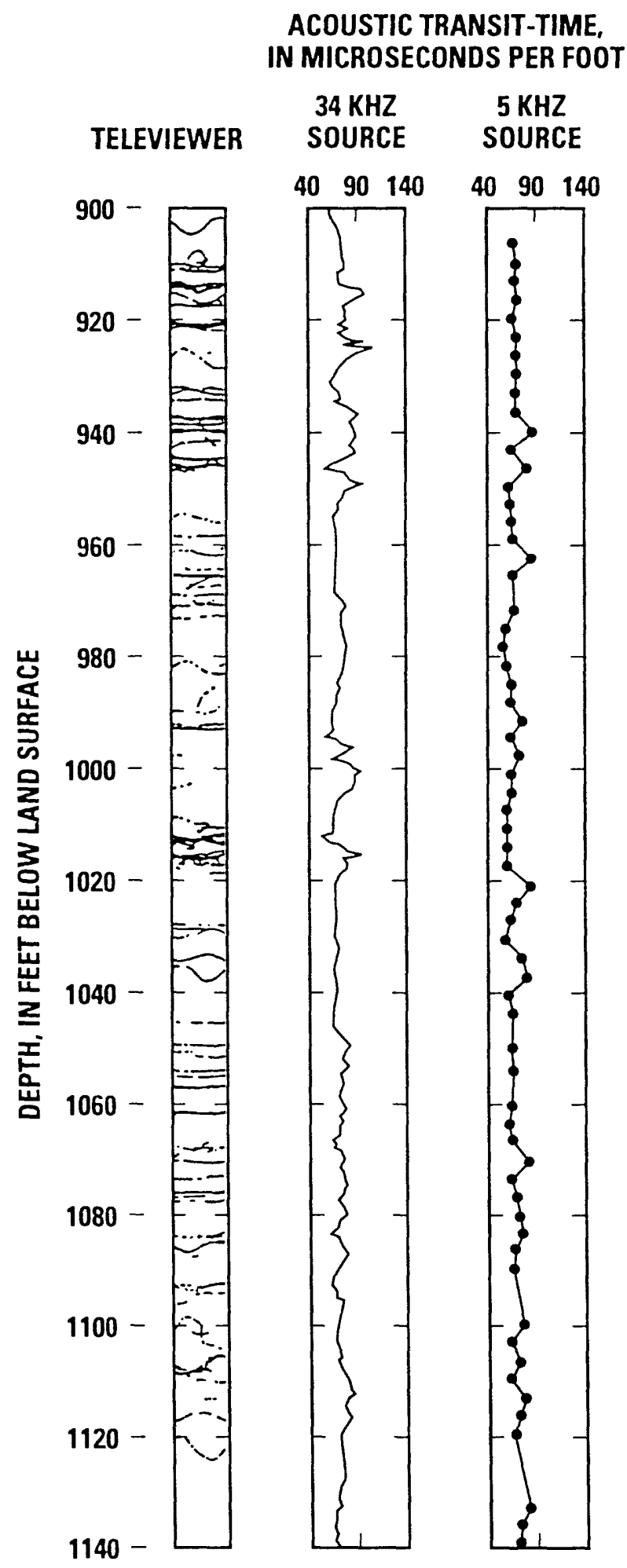

Figure 9. Borehole televiewer log and acoustic velocity measurements given by the conventional acoustic (34 $\mathrm{kHz}$ ) and the shear suspension $(5 \mathrm{kHz})$ logging systems for the depth interval from 900 to 1140 . 

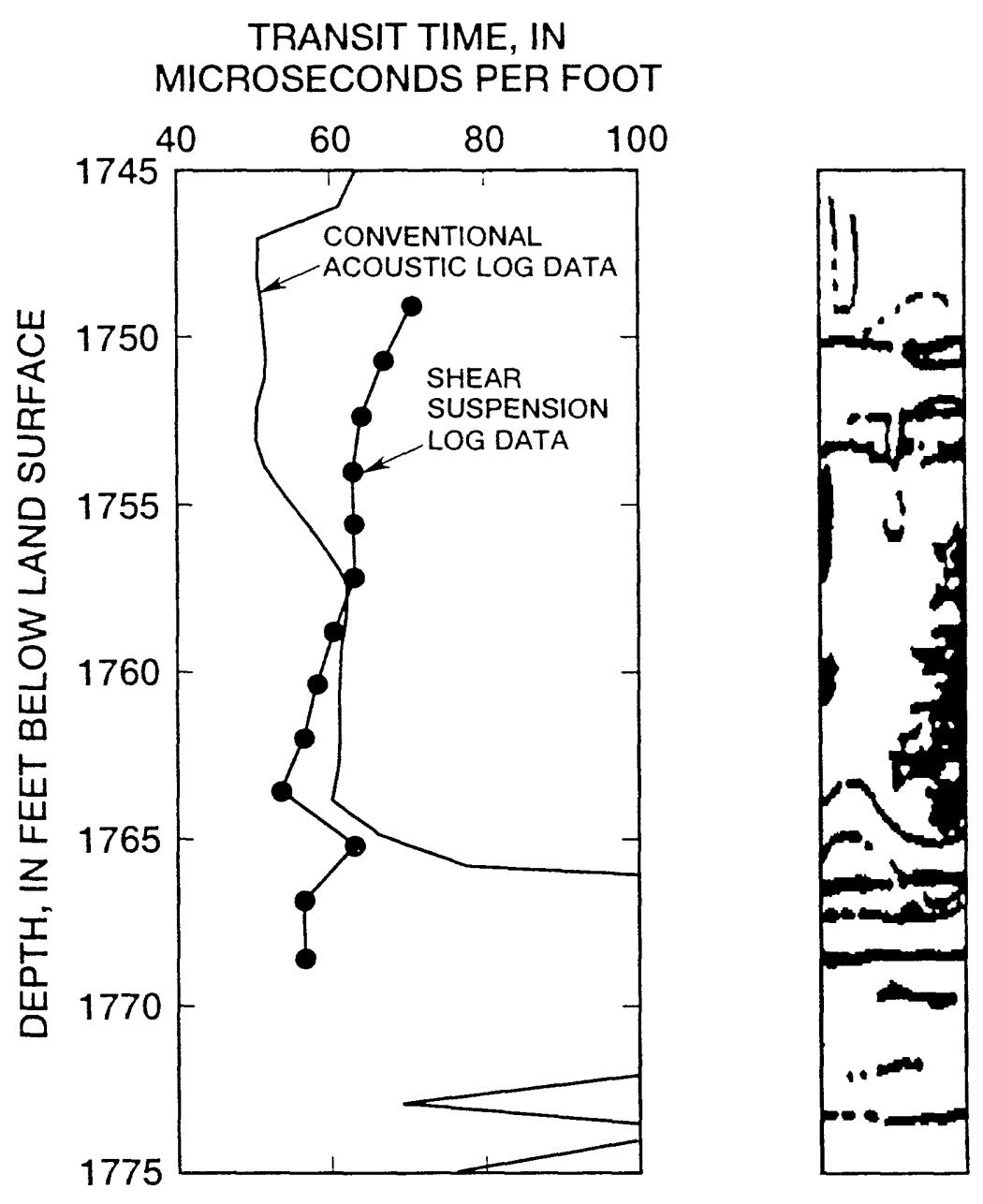

Figure 10. Borehole televiewer log and acoustic velocity measurements given by the conventional acoustic and shear suspension logging systems for the depth interval from 1740 to 1760 feet. 


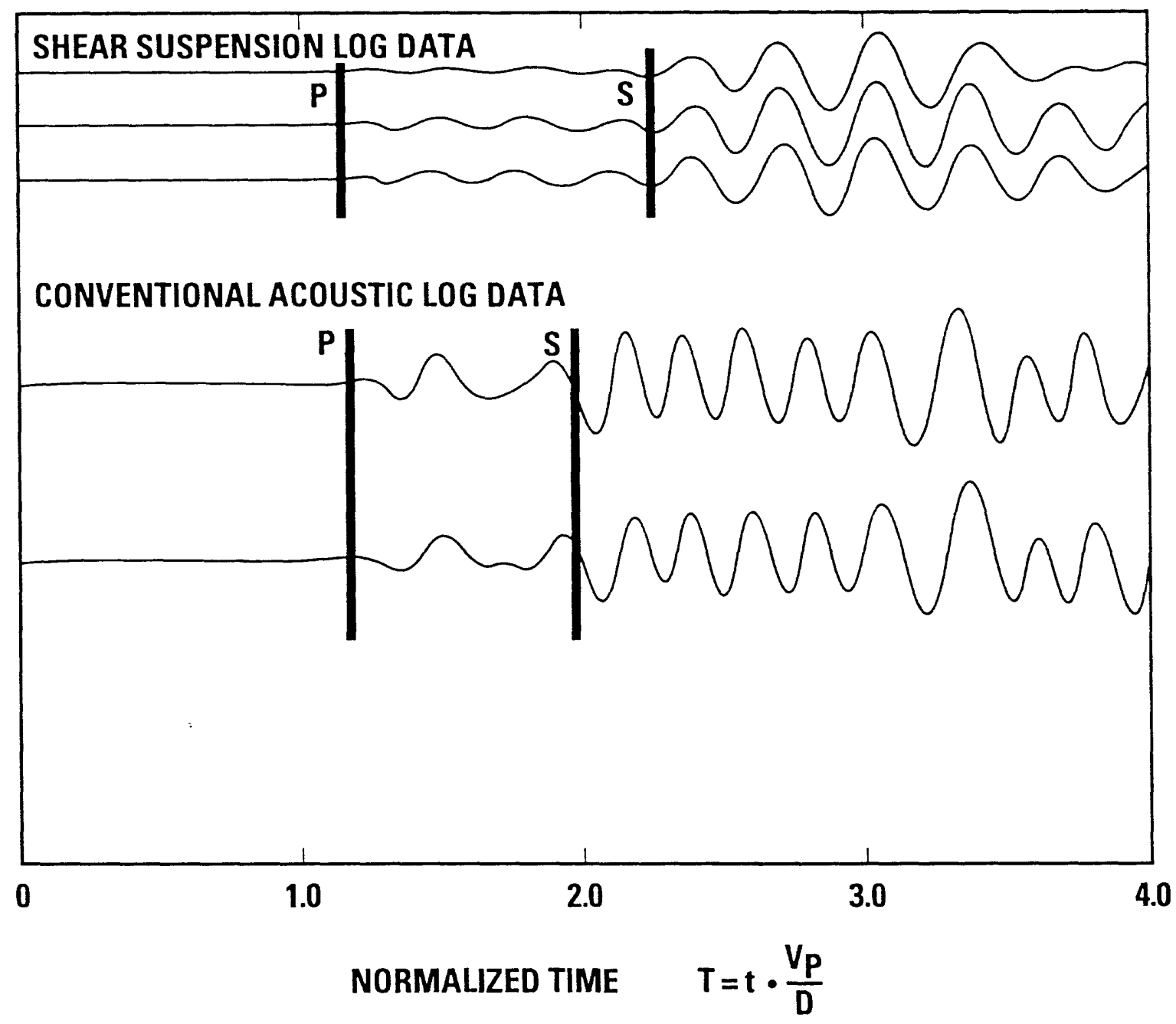

Figure 11. Example of waveforms obtained near 1745 feet in depth using shear suspension and conventional acoustic logging systems and compressional (p) and shear (s) arrival time picks. 
data with depth. In this approach, the vicinity of casing serves as a definite reference point, and the lack of variation in the data with depth means that there will be litthe error if there is a slight difference in depth scale.

The comparison of the two sets of waveforms show that compressional arrivals occur at about the same normalized time in each record, but that the shear arrival is somewhat earlier in the conventional log data (fig. 11). The shear suspension source is designed to produce mostly shear propagation in the formation, but the suspension source does excite a small compressional wave. The difference in shear arrival time in the two records is probably related to the physical mechanisms of wave propagation stimulated by the two different source mechanisms. The conventional source produces an axisymmetric (monopole) signal which propagates as a series of guided wave modes along the borehole. The shear arrival in the conventional acoustic waveform data represents a shear head wave, which is known to propagate with a velocity exactly equal to the shear velocity of the formation (Paillet and Cheng, 1986). The suspension logging system uses a nonsymmetric (dipole) source which induces more of the source energy to propagate as shear in the formation, but where the wave motion consists of dispersive wave pulses. The suspension log source excites the lowest dipole mode, which is excited by frequency values in the range of $3-8 \mathrm{kHz}$. The group velocity for these modes is known to be slightly slower than the shear velocity of the formation (Paillet and Cheng, 1991). Model studies show that the shear arrivals given by dipole logs give a useful relative estimate of shear velocity, but these relative estimates must be increased by an empirical factor of about 1.1 to give a true shear velocity value. This mechanism probably explains the difference between the two shear arrivals in figure 11 .

Another approach to the evaluation of shear velocity measurements is to use the ratio of compressional to shear velocity, $\mathrm{V}_{\mathrm{p}} / \mathrm{V}_{\mathrm{s}}$, to estimate the Poisson ratio, $v$, of the formation. The Poisson ratio is related to the compressional and shear velocities of a formation by the equation (White, 1983):

$$
v=(A-2) /[2 *(A-1)] \text { where } A=V_{p}{ }^{2} / V_{s}{ }^{2}
$$

Poisson ratio values for natural materials range from 0.5 for a liquid to about 0.4 for clay and shale to between about 0.25 and 0.30 for crystalline rocks such as basalt and granite. In the shear suspension log data analysis, a compressional velocity of about $16,000 \mathrm{ft} / \mathrm{s}$ typically corresponds with shear velocity ranging from
6,980 to $7,800 \mathrm{ft} / \mathrm{s}$, corresponding to $\mathrm{V}_{\mathrm{p}} / \mathrm{V}_{\mathrm{s}}$ ratios of 2.3 to 2.0. The average value of the ratio for the shear suspension log data is about 2.2. In contrast, the conventional acoustic log waveform analysis shown in figure 8 gives a $\mathrm{V}_{\mathrm{p}} / \mathrm{V}_{\mathrm{s}}$ of 1.93 . Therefore, the shear suspension log data estimate a Poisson ratio of 0.34 to 0.38 compared to a value of 0.315 from the conventional acoustic waveform analysis. Although these are just examples from a variable data set, the many compressional and shear velocity values given by the suspension log analysis seem to correspond to Poisson ratio values that are consistently greater than those expected for basalt. This inconsistency could be explained by a consistent underestimate of shear velocity in the formation.

\section{SUMMARY}

Geophysical well logs run under five different casing conditions during the drilling and removal of casing from borehole ANL-OBS-A-001 can be depthadjusted to provide a very good correlation with detailed core descriptions. Borehole televiewer image logs provide useful information regarding the details of fractures and basalt interflow openings in situ, and allow the proper positioning of fragmented core or recovered core sections where short intervals have been lost. Borehole flow' logs indicate the specific features described on core and indicated on geophysical $\operatorname{logs}$ that are associated with inflow to and outflow from the borehole under ambient hydraulic head conditions under several different combinations of open and cased hole intervals. Although conventional acoustic transittime logs provided little additional direct information about formation lithology, the acoustic logs and a short interval of acoustic waveform log data were useful in evaluating the results from shear suspension logging. The acoustic transit-time logs give measurements of acoustic transit time that agree with those from the suspension logging, except in the interval below 1735 in depth where the near receiver data obtained in the suspension logging were not reliable. However, comparison of waveforms obtained from the acoustic and suspension logging probes indicates that shear velocity estimated from the suspension log waveforms may underestimate shear velocity in the formation if the dispersive effects of the dipole source in the suspension logging system are not accounted for by relating measured wave group velocity to the actual shear velocity of the formation. 


\section{REFERENCES}

Chen, S. T., 1988, Shear wave logging with dipole sources: Geophysics, v. 53, p. 659-667.

Hearst, J. R. and P. H. Nelson, 1985, Well logging for physical properties: New York, McGraw-Hill, $570 \mathrm{p}$.

Hess, A. E., 1986, Identifying hydraulically conductive fractures with a flowmeter: Canadian Geotechnical Journal, v. 23, no. 1, p. 69-78.

Hess, A. E. and F. L. Paillet, 1990, Applications of the thermal-pulse flowmeter in the hydraulic characterization of fractured rocks, in Paillet, F. L. and Saunders, W. R., eds., Geophysical Applications for Geotechnical Investigations: American Society for Testing and Materials, Standard Technical Publication 1101, p. 99-112.

Keys, W. S., 1990 Borehole geophysics applied to ground-water studies: U. S. Geological Survey Techniques of Water Resource Investigations, book 2,chap. E2, 150 p.

Kitsunezaki, C., 1980, A new method for shear wave logging: Geophysics, v.45, p. 1489-1491.

Paillet, F. L., 1993, Application of borehole geophysics in the characterization of fractured rocks: U.S. Geological Survey Water-Resources Investigation Report 93-4214, 36 p.

Paillet, F. L. and C. H. Cheng, 1986, A numerical investigation of head waves and leaky modes in boreholes: Geophysics, v. 51, p. 1438-1447.

Paillet, F. L. and C. H. Cheng, 1991, Acoustic waves in boreholes: Boca Raton, Florida, CRC Press, $264 \mathrm{p}$.

Paillet, F. L., A. E. Hess, C. H. Cheng, and E. L. Hardin, 1987, Characterization of fracture permeability with high resolution vertical flow measurements during borehole pumping: Ground Water, v. 25, no. 1, p. 28-40.

White, J. E., 1983, Underground sound - application of seismic waves: Amsterdam, Elsevier, 253 p. 